\title{
Influence of dietary conjugated linoleic acid (CLA) on the fatty acid content and CLA profile of egg yolks in laying hens ${ }^{*}$
}

\author{
M. Czauderna ${ }^{1,3}$, J. Kowalczyk ${ }^{1}$, P.M. Pisulewski ${ }^{2}$ and K. Korniluk ${ }^{1}$ \\ ${ }^{1}$ The Kielanowski Institute of Animal Physiology and Nutrition, Polish Academy of Sciences \\ 05-110 Jabłonna, Poland \\ Agricultural University of Cracow, Department of Human Nutrition, \\ al. 29 Listopada 46, 31-425 Kraków, Poland
}

\begin{abstract}
Two groups of nine hens were fed a control diet or a diet supplemented with $7.5 \mathrm{~g} / \mathrm{kg}$ CLA preparation for 5 weeks. Eggs were collected in the last week and their fatty-acid (FA) profile in yolks determined. Dietary CLA resulted in increased contents of saturated FA and CLA isomers, especially cis-9, trans- 11 and $t t$ CLA, decreased the content of mono- and polyunsaturated FA. The increased content of CLA isomers and reduced content of arachidonate in egg yolks can be considered beneficial for human health.
\end{abstract}

KEY WORDS: conjugated linoleic acid, fatty acids, egg yolk lipid, hen

\section{INTRODUCTION}

In view of growing interest in functional foods in Europe, the development of animal products, including eggs, enriched with polyunsaturated fatty acids (PUFA, e.g. $n-3$ ) and conjugated linoleic acid (CLA), may have a positive impact on consumers' health. Generally, various nutritional strategies have been used to obtain PUFA- or CLA-enriched animal products, i.e. milk, meat and eggs. Among these products, CLAenrichment of eggs was frequently reported (Szymczyk and Pisulewski, 2003, 2005). More recently, CLA-enriched eggs were found to be less susceptible to oxidation.

Nutritional strategies are considered a natural means of enriching animal products with functional components. However, they may be potentially deleterious. Therefore the outcome of such strategies should be strictly controlled. The objective of this study was to examine the effect of feeding CLA isomers to laying hens on the level of CLA isomers and other fatty acids (FA) in hen egg yolks.

\footnotetext{
${ }^{*}$ Supported in part by the State Committee for Scientific Research, Grant No. 3P06T 02924

${ }^{3}$ Corresponding author: e-mail: m.czauderna@ifzz.pan.pl
} 


\section{MATERIAL AND METHODS}

Eighteen 25-week-old laying hens (Hy-Line Brown) were equally distributed to 2 groups and maintained in individual cages for 5 weeks. The control group was fed a commercial layer diet supplying $2 \%$ sunflower oil, while the second group

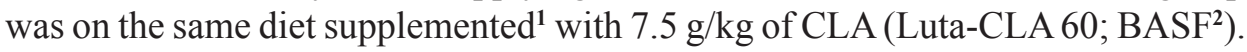
Eggs from each hen, collected on week 5 of the experiment ${ }^{3}$, were broken, yolks separated from albumen, and freeze-dried. The powdered yolk mass from control hens was averaged by mixing. For preparation of yolk mass from hens fed a diet with CLA, one sample of material was prepared by mixing all yolk. FAs were saponified and methylated as described previously (Czauderna et al., 2003, 2005). Separation of FA methyl esters was carried out using GLC, while FA-containing conjugated double bonds were separated using $\mathrm{Ag}^{+}-\mathrm{HPLC}$, with $\mathrm{UV}$ detection at $234 \mathrm{~nm}$ (Czauderna et al., 2005).

\section{RESULTS AND DISCUSSION}

The CLA diet induced accumulation of CLA isomers and altered the content of other FAs in egg yolk lipids in comparison with control eggs (Table 1). As expected, trans, trans (tt), cic, cis (cc) and cis-9, trans-11CLA (c-9,t-11 CLA) were preferentially incorporated into yolk lipids, compared with the fatty acid profile of dietary CLA. Moreover, the number of $t t$ isomers in yolks exceeded the number of $t t$ CLA isomers fed. This is consistent with a study (Czauderna et al., 2004) in which the number of $t$ isomers, their relative contribution and the ratio of $c-9, t-11$ CLA to total CLA in rat livers were considerably higher than in the dietary CLA preparation. Szymczyk and Pisulewski (2003, 2005) provided evidence that $t 10, c 12$ and $t 10, t 12$ isomers were more efficiently metabolised by animals than their $c 9, t 11$ homologues, and consequently the ratio of $c 9, t 11$ to $t 10, c 12$ was higher than that in dietary CLA (3.34 vs 1.06, respectively). The preferential accumulation of $t t$ isomers in yolks from hens fed the CLA diet could have resulted from their slower metabolism and preferred geometric incorporation into phospholipids; moreover $t t$ isomers are poor substrates for $\beta$-oxidation. Detailed analyses of $\mathrm{Ag}^{+}$-HPLC chromatograms showed that small amounts of $c 11, t 13(0.17 \%)$ and $t 8, c 10(5.02 \%)$ CLA isomers were incorporated into yolks. In view of the beneficial (anti-obesity, anti-atherogenic and anti-inflammatory)

\footnotetext{
${ }^{1}$ as a replacement of sunflower oil

${ }^{2}$ profile of the dietary CLA isomer mixture: $t 11 t 13,0.08 \% ; t 10 t 12,3.83 \% ; t 9 t 11,3.84 \%$; $t 8 t 10$, $0.11 \% ; t 10 c 12,44.02 \% ; c 9 t 11,46.67 \% ; c 10, c 12,0.71 \% ; c 9, c 11,0.73 \%$

${ }^{3}$ average collected egg weight: 6.48 and $6.51 \mathrm{~g}$ egg mass/hen from the control and experimental groups, respectively
} 
health-related effects of CLA isomers in animals and humans, their enhanced incorporation into eggs may be considered beneficial.

Dietary CLA increased the content of saturated fatty acids (SFA), and reduced that of mono- and polyunsaturated fatty acids (MUFA, PUFA); this is consistent with the findings of Szymczyk and Pisulewski (2003, 2005). The increased content of SFA and the concomitant decrease in the MUFA content

Table 1. Effect of dietary CLA ${ }^{1}$ on fatty acid level (as arithmetic means) in hen egg yolks

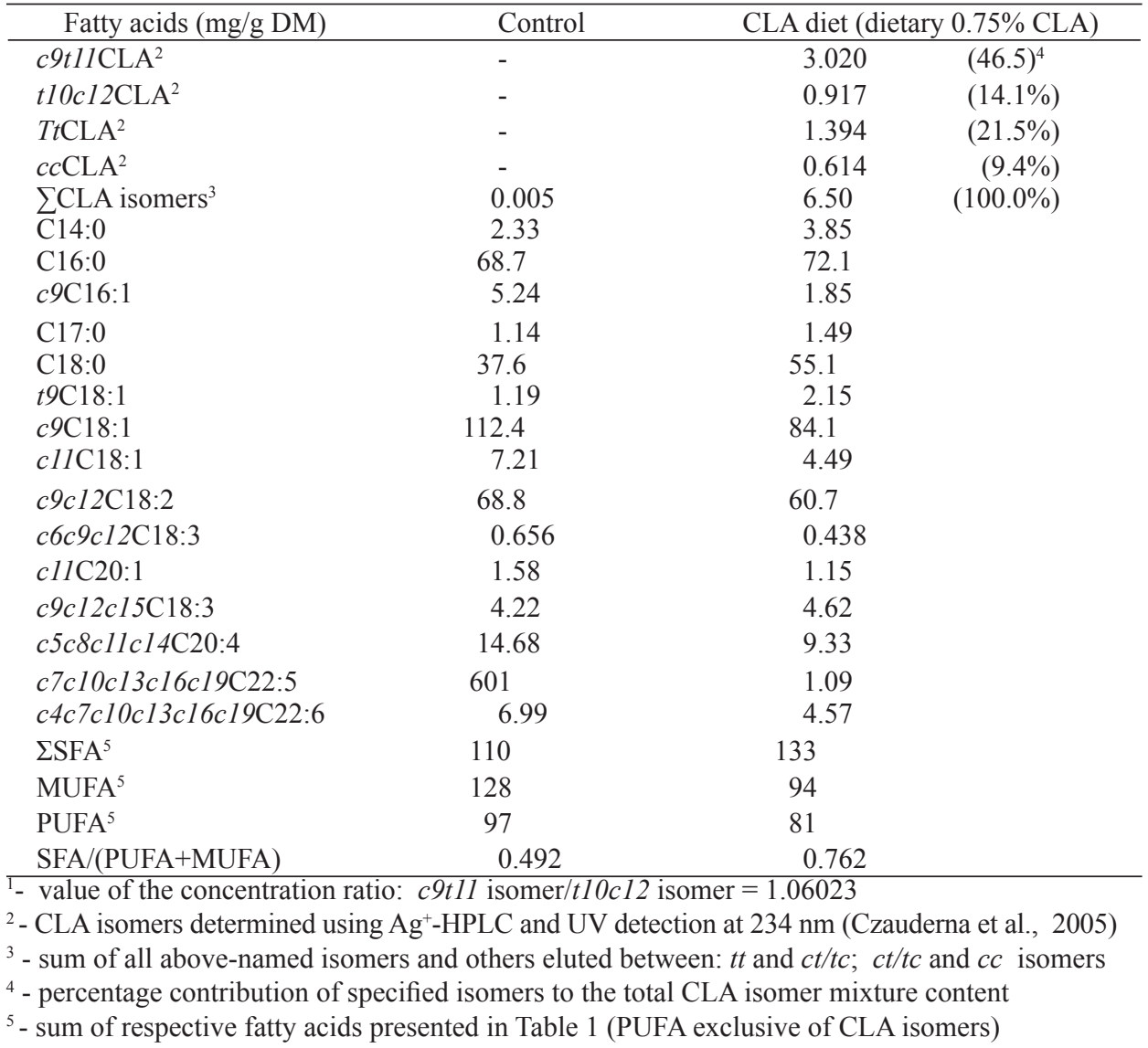

could result from inhibition of $\Delta 9$-desaturase in hens similarly as in porcine adipose tissue. The decreased content of C18:2n-6 in CLA yolk was probably due to substituting the CLA oil for sunflower oil (control). On the other hand, the decreased contents of derivatives of C18:2n-6 and C18:3n-3 could imply that CLA isomers compete with both $\mathrm{C} 18: 2 n-6$ and $\mathrm{C} 18: 3 n-3$ for $\Delta 6$-desaturase, the rate-limiting enzyme for the conversion of these FAs into C20:4n-6 and C22:6n-3, respectively. Since arachidonate, acting as a substrate for cyclooxygenase (COX) 
and lipooxygenase (LOX), gives rise to synthesis of proinflammatory eicosanoids (PG, TX and LT), its decreased content in eggs may be considered beneficial. According to recent findings, pro-inflammatory effects, inducing inflammatory reactions in the human body, may be responsible for a number of diseases, including atherosclerosis and cancer.

\section{CONCLUSIONS}

The finding that CLA isomers, especially $c-9, t-11$, are effectively incorporated into egg yolk lipids, makes hen eggs ideal targets for nutritional modification and development of functional foods that exert beneficial effects on human health. The ability of CLA to decrease the arachidonate content in yolk lipids enhances even further the functional properties of modified eggs. However, adverse changes in yolk FA profile (i.e. increased SFA content and decreased MUFA and PUFA content), suggest that further study in this field is warranted.

\section{REFERENCES}

Czauderna M., Kowalczyk J., Korniluk K., Wąsowska I., 2005. Improving the analysis of fatty acids using combination of gas chromatography and $\mathrm{Ag}^{+}$liquid chromatography. J. Anim. Feed Sci. 14, Suppl.1, 563-566

Czauderna M., Kowalczyk J., Niedźwiedzka K.M., Wąsowska I., Pastuszewska B., Bulska E., Ruszczyńska A., 2004. Liver and body mass gain, content of CLA isomers and other fatty acids in the liver of rats fed CLA isomers and selenium. J. Anim. Feed. Sci. 13, 353-369

Czauderna M., Kowalczyk J., Wąsowska I., Niedźwiedzka K.M., 2003. Determination of conjugated linoleic acid isomers by liquid chromatography and photodiode array detection. J. Anim. Feed Sci. 12, 269-382

Szymczyk B., Pisulewski P.M., 2003. Effects of dietary conjugated linoleic acid on fatty acid composition and cholesterol content of hen egg yolks. Brit. J. Nutr. 90, 93-99

Szymczyk B., Pisulewski P.M., 2005. Effect of conjugated linoleic acid and vitamin E on fatty acid composition and cholesterol content of hen egg yolks. J. Anim. Feed Sci. 14, 109-123

\section{STRESZCZENIE}

\section{Wpływ dodatku sprzężonego kwasu linolowego (CLA) do diety kur na zawartość kwasów tluszczowych i profil izomerów CLA w żóltku jaj}

Celem pracy była ocena wpływu żywienia kur niosek paszą z dodatkiem izomerów sprzężonego kwasu linolowego (CLA), na ich zawartość oraz zawartość innych kwasów tłuszczowych (FA) w żółtku jaja. Żółtka jaj niosek żywionych mieszanką o zawartości 0,75\% CLA zawierały więcej izomerów CLA, oraz nasyconych FA a mniej jedno- i wielonienasyconych FA. Podwyższony poziom CLA i niższa zawar-tość kwasu arachidonowego w zmodyfikowanych żywieniowo jajach są cechami determinującymi ich potencjalne korzystne oddziaływanie na organizm człowieka. 